\title{
XVII
}

\section{Moral Emotions in Dostoevsky's “The Dream of a Ridiculous Man”}

\author{
Deborah A. Martinsen
}

Dostoevsky's "The Dream of a Ridiculous Man" is a philosophical tale that explores the emotional dynamics of its eponymous first-person narrator. "Dream" recounts the story of a "vile Petersburgian" infected by Western Enlightenment thinking who sees a little star in the dark sky, decides to commit suicide, encounters a little girl who begs him for help, feels pity then anger, drives her away, returns home, speculates about his emotions, has a dream vision of an Edenic paradise that floods him with love, and awakens with a thirst for life. ${ }^{1}$ His story recounts the conversion of a fallen man whose journey of self-knowledge gives him a life-saving dream vision that includes a version of the Christian myth of paradise, fall, and redemption. His story reflects Dostoevsky's message that beauty can save us: the Ridiculous Man starts with

1 Noteworthy studies of "Dream" include Joseph Frank, Dostoevsky: The Mantle of the Prophet, 1871-1881 (Princeton, NJ: Princeton University Press, 2003), 351-58; Robert Louis Jackson, The Art of Dostoevsky: Deliriums and Nocturnes (Princeton, NJ: Princeton University Press, 1981), 272-303; Robin Feuer Miller, Dostoevsky's Unfinished Journey (New Haven, CT: Yale University Press, 2007): 105-27, 148-61; Gary Saul Morson, The Boundaries of Genre: Dostoevsky's "Diary of a Writer" and the Traditions of Literary Utopia (Austin: University of Texas Press, 1981): 177-82; and V. Tunimanov, "Satira i utopiya ('Bobok,' 'Son smeshnogo cheloveka’ F.M. Dostoevskogo),” Russkaia literatura 9, no. 4 (1966): 70-87. 
a narrow view of the world, has a dream that expands his vision, and awakens with a living image of truth, beauty, and unity in his heart. The story's emotional dialectic mirrors its mythic vision: the Ridiculous Man starts from a position of flat affect (his chronic shame has given rise to negative emotions and defenses that inure him to the greater emotional pain of feeling unlovable), his encounter with the little girl and his dream vision flood him with positive emotions that break down his emotional defenses, and his love for others persists after he awakens. I will examine the Ridiculous Man's spiritual awakening by focusing on two images - the little star in the sky and the little girl on the earth — and four of the story's salient moral emotions — pity, shame, pride, and toska, a particularly Russian anguish that signals metaphysical longing in Dostoevsky's work.

Following the philosophers Gabriele Taylor and Jesse Prinz, I hold that moral emotions are characterized by their evaluative and moral dimensions, that is, they help us recognize whether an action is bad, and they motivate us to be good. ${ }^{2}$ On these terms, not all emotions are moral: fear for one's life is not, whereas fear for one's soul is. Since moral emotions entail judgment, they awaken both our cognitive and affective capacities - a dual action Dostoevsky deploys to involve us in the action and affect of his writing. In exploring the moral function of toska, I am extending the work of Arpad Kovacs, who shows that toska has ontological, aesthetic, and poetic functions in Dostoevsky's work. ${ }^{3}$ I will also show that toska, like shame, works by paradox: in both emotions, the underlying sense of alienation heightens the sense of lost or desired connection. ${ }^{4}$

In "Dream," Dostoevsky lays bare the dismantling of emotional defenses that the philosopher David Velleman argues is essential to the opening of our hearts. ${ }^{5}$ Whereas the story's first-person narrator protects himself from the

2 Gabriele Taylor, Deadly Vices (Oxford: Clarendon, 2006), 55; Jesse Prinz, "The Moral Emotions," The Oxford Handbook of Philosophy of Emotion, ed. Peter Goldie (Oxford University Press, 2010), 520.

3 Arpad Kovacs, "Angustia: Toska u Dostoevskogo," in Russica Hungarica: Issledovaniya po russkoi literature $i$ kul'ture, Rusistika v Budapeshtskom Universitete imeni Etvesha Loranda (Budapest-Moscow, 2005), 100-25. I cite a manuscript copy whose pages do not correlate to the volume's pages.

4 Unlike shame, toska does not primarily stem from feelings of personal inadequacy, although it can express similar feelings of social and metaphysical loss. Moreover, unlike shame, which often paralyzes a person emotionally, toska often impels a person not only to express that sense of longing, as Kovacs demonstrates, but also to seek something outside the self.

5 J. David Velleman, “Love as a Moral Emotion," Ethics 109, no. 2 (1999): 338-74. 
shame and pain of being considered ridiculous with walls of pride, ratiocination, and indifference, his unexpected pity for the little girl exposes the falsity of his self-protective self-image and breaks down those defenses. His pity arouses his anger, his philosophical speculation distances him from unsettling emotions, and his dream reconciles mind and heart. Dostoevsky thus engages the Romantic debate with Enlightenment thinking ${ }^{6}$ and devises a synthesis that heals his Ridiculous Man's divided self. Dostoevsky's solution also resembles his doctrine of pochvennichestvo - a union of native Russian moral intuition and imported European education that can heal the rift between Russia's noneducated and educated populations.

While the story has many generic sources, I will show how Dostoevsky turns "Dream" as a philosophical tale into a Christmas story. ${ }^{7}$ Dostoevsky signals his engagement with Enlightenment thinking by explicitly referring to Voltaire throughout the story. First, he draws attention to the story's genre as a philosophical tale by having the Ridiculous Man note that he is sitting in a Voltairean armchair, first as he speculates, then as he dreams. Next, by having the Ridiculous Man confess his intention to shoot himself in the head yet dream that he shoots himself in the heart, Dostoevsky underscores the story's mindheart thematics. Finally, by evoking Voltaire's philosophical tale "Micromegas," whose eponymous space-traveling philosopher hails from Sirius, Dostoevsky highlights his narrator's penchant for rational analysis. By contrast, Dostoevsky's implicit references to Dickens's A Christmas Carol signal his intention to combat Enlightenment rationality with Romantic sentiment. Pity for a child in pain will open a heart that has defended itself from the vulnerability of connection. ${ }^{8}$

6 Frank, Mantle of the Prophet, 357. Frank argues that although Dostoevsky's story has similarities to Cabet's Voyage to Icaria and Victor Considerant's La Destinée sociale, which reflect his utopian socialist roots and moral sympathies, "Dream" is written "as an answer to the rational utopias of the Socialists.” He agrees with N. I. Prutskov that Dostoevsky's story is not anti-utopian but anti-Enlightenment: "Its foundation is anti-Enlightenment (the primacy of feelings of the heart and their opposition to truths of the head, the precedence of moral actions prompted by conscience in opposition to those actions motivated by convictions)"; Prutskov, "Utopia ili anti-utopia," in Dostoevsky i ego vremya (Leningrad, 1971): 352.

7 Miller, Dostoevsky's Unfinished Journey, 105-27.

8 Ibid., 121. Miller continues, "The paradoxical notion of a preacher who knows he has lost the knack for words renders his life, rather than his words about that life, a living symbol of faith as opposed to reason" (ibid.). 
The little star and the little girl initially represent the Ridiculous Man's mind-heart conflict. In the biblical Christmas tale, a star in the sky signals hope and inspires three wise men to journey to Bethlehem. In "Dream," the little star extinguishes hope and inspires the Ridiculous Man to kill himself. When the Ridiculous Man sees that same little star again during his dream journey, he mistakes it for Sirius. In evoking Voltaire's tale, which explores how one's sense of self affects one's perspective, Dostoevsky suggests that Enlightenment thought has perverted his narrator's thinking. ${ }^{9}$ Read as part of Dostoevsky's 1876-77 Diary of a Writer's polemic on suicide, this story illustrates the limits of the Ridiculous Man's moral imagination: instead of marveling at the vastness of the universe and the fact that he is part of it, the Ridiculous Man feels metaphysically insignificant. ${ }^{10}$ As the psychiatrist Richard Rosenthal observes, the Ridiculous Man uses suicide as a defense: "He carries it around in his back pocket, so to speak, as the ultimate escape. When he feels inadequate, rejected, and humiliated, he can always kill himself. This gives him a sense of control."11 Comforted by the thought that he has determined the moment to kill himself, the Ridiculous Man heads to his fifth-floor room, a location that signals both his poverty and his alienation from the life-giving Russian soil.

The little girl shows that the Ridiculous Man's mental construct is false. She needs him. Anticipating Zosima's doctrine that all are responsible for all, Dostoevsky shows readers that the Ridiculous Man can help the little girl. But he doesn't, and the Ridiculous Man cannot kill himself without speculating on why his commitment to non-being does not nullify either his "feeling of pity for the little girl" or "his feeling of shame after the base act committed" (PSS, 25:108). These two emotions-pity (zhalost') and shame $(s t y d)$-dramatize the Ridiculous Man's internal conflict. His pity is a positive, other-directed emotion, and his shame is a negative, self-directed emotion.

9 Voltaire's tale "Micromegas" also explores how rational inquiry affects belief.

10 Dostoevsky opens his 1876 Diary of a Writer with reflections on suicide, and he contrasts contemporary, unthinking suicides with Goethe's Werther, who bids farewell to the Milky Way, thereby signaling his sense of connection to God's creation (PSS, 22:6). I cite F. M. Dostoevsky, Polnoe sobranie sochinenii v tridtsati tomakh [PSS], ed. V. G. Bazanov et al. (Leningrad: Nauka, 1972-1990), as PSS by volume and page. All translations are my own.

11 Richard J. Rosenthal, M.D., email correspondence, January 23, 2014. I am grateful to Richard for sharing his thoughts and insights about the story with me as I wrote this article; they were a tremendous help in formulating my own. 
The elided emotion-anger-momentarily protects him from the pain of sympathy. Dostoevsky's readers will recognize this underground dynamic: the positive emotion's heart-flooding affect threatens the individual's sense of self, and he or she responds by withdrawal, aggression against self, or another, or both.

The Ridiculous Man identifies with the little girl's fear: "in her voice resonated that sound, which in very frightened children signifies despair. I know that sound" (PSS, 25:106). In short, the little girl instantiates the Ridiculous Man's fear of isolation, exclusion, or abandonment. This identification arouses his pity-a positive emotion that entails the capacity to imagine another's pain. The little girl's words_ "Mamochka! Mamochka!” (25:106)_activate the Ridiculous Man's moral imagination. He understands "that her mother is dying somewhere, or something had happened there with them, and she ran out to call someone, to find something to help her mama” (25:106). The little girl's pain and fear breach the Ridiculous Man's hardened emotional defenses and open his eyes. He recognizes how much she loves and depends on her mother and how terrified she is of losing her. His spontaneous pity reveals the Ridiculous Man's innate moral sensitivity, but her vulnerability reminds him of his own. His anger exposes his defenses against the pain of vulnerability and the shame of not living up to his ideals. ${ }^{12}$

The little star and the little girl, signs of head and heart, heavens and earth, alienation and connection, are also linked to the Ridiculous Man's toska, his anguished longing for wholeness or belonging. As Nabokov explains, "No single word in English renders all the shades of toska. At its deepest and most painful, it is a sensation of great spiritual anguish, often without any specific cause. At less morbid levels it is a dull ache of the soul, a longing with nothing to long for, a sick pining, a vague restlessness, mental throes, yearning." ${ }^{13}$ Kovacs shows that in Dostoevsky's early work, toska expresses an anguished longing for

12 People who pride themselves on their self-sufficiency or moral superiority see positive emotions as a sign of weakness. See Deborah A. Martinsen, "Shame and Punishment," Dostoevsky Studies 5 (2001): 51-70.

13 Aleksandr Pushkin, Eugene Onegin: A Novel in Verse, trans. with commentary by Vladimir Nabokov (Princeton, NJ: Princeton University Press, 1981), 2:141. This statement is found in Nabokov's commentary to chap. 1 , stanza 34 , line 8 . The quote continues, "In particular cases it may be the desire for somebody or something specific, nostalgia, love-sickness. At the lowest level it grades into ennui, boredom, skuka." 
an absent or nonexistent object, a desire for it, for beauty, for living life. ${ }^{14}$ Kovacs also demonstrates how toska simultaneously acts as both the signal and subject of narrativity, the symptom of will and its expression, an anguish for an unattained reality that leads to a need for expression and a search for new words. ${ }^{15}$ In "Dream," the Ridiculous Man's toska expresses an anguished longing for both human community and metaphysical unity. His toska also motivates the Ridiculous Man to articulate his vision.

Dostoevsky first introduces toska in the story's second paragraph as the Ridiculous Man confesses that "earlier I felt anguish because I seemed ridiculous" (PSS, 25:104). Using the verb form toskovat', he identifies his anguish with a sense of social alienation and painful self-awareness. Like his literary predecessor, the Underground Man, the Ridiculous Man acknowledges his painful self-awareness: he claims that he did not merely seem ridiculous, but actually was. The unnamed emotion here is shame: the Ridiculous Man feels insignificant and unlovable. Shortly thereafter, Dostoevsky explicitly ties his narrator's anguish to his indifference: "Perhaps because a terrible anguish was growing in my soul due to a certain circumstance that was already infinitely beyond me: namely the conviction that had come upon me that in the whole world nothing matters" (всё равно; emphasis in original) (25:105). The Ridiculous Man's mind has strangled his heart with a philosophy of indifference that protects him from painful self-consciousness and "terrible anguish." He uses the language of revelation-his conviction arises "suddenly" (вАруг) and he feels it with his "whole being" (25:105). In fact, from the moment that the narrator accepts his indifference, he "suddenly stopped feeling angry" (25:105). Behind his narrator's back, Dostoevsky informs us that the Ridiculous Man's philosophy of

14 Kovacs, "Angustia," 13. I indicate page numbers from my printout. Kovacs argues that the untranslatable toska derives from the concept of angustia as used variously in the works of St. Augustine, Martin Luther, Pascal, Kierkegaard, Berdyaev, Heidegger, and Tillich. Kovacs asserts that even though toska is not synonymous with German Angst, it more closely approaches the German and French sense of existential angst (1). Unlike depression in Dostoevsky's work, which is negatively associated with pointless ideation, fantasy, and images of darkness and shadows, toska is positively associated with insightfulness (прозрение), the heart, and images of light (10). It entails a suffering that derives from others' suffering and that concentrates our sympathy for them (11). Finally, toska simultaneously and paradoxically signals a constriction of the heart and a longing for something beyond it (15).

15 Ibid., 9-12. 
indifference is a perverse emotional defense against awareness. ${ }^{16}$ Like the Underground Man, he bumps into people on the street, but unlike the Underground Man, who hones his painful self-consciousness and spends months preparing for a sidewalk duel to restore his honor, the Ridiculous Man dulls his.

By linking the Ridiculous Man's “terrible anguish” to something "infinitely higher," Dostoevsky stresses the metaphysical dimension of his narrator's alienation. He also supplies a solution: the Ridiculous Man's dream reconnects him to his positive emotions. Unlike Voltaire's Sirian philosopher Micromegas, who travels the external universe seeking knowledge about other worlds, Dostoevsky's Ridiculous Man seeks answers to moral questions by dream travel: "Dreams, it seems, are impelled not by rationality, but desire, not the head, but the heart" (PSS, 25:108). ${ }^{17}$ His dream companion saves him from his self-enclosed hyperrationality by taking him outside of himself-beyond the earth, past the stars, to a prelapsarian paradise. The Ridiculous Man's dream vision turns his thoughts toward the divine: "How could I alone conceive it or dream it with my heart? Is it possible that my petty heart and capricious, insignificant mind could be elevated to such a revelation of truth?” (25:115). The Ridiculous Man's inner journey of self-knowledge thus leads him to a reality outside and higher than himself.

The Ridiculous Man's higher reality is associated with images of light, which Kovacs connects to toska in Dostoevsky's early work. ${ }^{18}$ In part 3 of this 1877 story, the Ridiculous Man feels a terrible anguish while traveling through space: "I expected something in the terrible anguish tormenting my heart" (PSS, 25:111). ${ }^{19}$ Yet no sooner does the Ridiculous Man feel toska-not in the past but in the present - than he sees the sun, which resurrects him: "I suddenly

16 Here I am adopting Melvin Lansky's model of defense as "defense against awareness"; Melvin R. Lansky, "Hidden Shame," Journal of the American Psychoanalytic Association 53 (2005): 870.

17 Moreover, dreams do not follow the rules of logic: the Ridiculous Man knows that he is dead, but also that he continues to feel and think. In dream logic, feelings come first.

18 Kovacs, "Angustia," 10.

19 Dostoevsky shows readers his first-person narrator's emotional defenses (PSS, 25:110-11): the Ridiculous Man anticipates humiliation, exposes his fear of contempt to his traveling companion, and then experiences humiliation for revealing his fear (a very underground dynamic). Voltaire describes a similar experience, one regarding rational prejudices rather than emotional defenses: Micromegas and his companion from Saturn initially dismiss the possibility that earth's inhabitants could have intelligence because of their relative minuteness, which Micromegas then realizes is an intellectual prejudice with no basis in reality. 
saw our sun! ... the native power of light, that same light that gave birth to me, resounded in my heart and resurrected it, and I felt life, my former life, for the first time since my grave" (25:111). The clear Christian imagery of this second revelation undoes the Ridiculous Man's earlier revelation that nothing matters. It also emphasizes the Augustinian connection between self-knowledge and knowledge of the divine-to know oneself is to know God in oneself. In the Ridiculous Man's story, as in Augustine's Confessions, confession is both acknowledgment of shortcoming and profession of faith.

In part 4, as the Ridiculous Man notes that his hatred for people on earth always included toska, Dostoevsky links toska and the moral emotions. The Ridiculous Man can only understand the prelapsarian dream people with his heart. He claims that they elicit a "responding anguish" in "the dreams of his heart" (в снах моего сердце) and "the dreams of his mind" (в мечтах ума моего). As in Crime and Punishment, Dostoevsky employs the Russian word son to signify unconscious dreams, like Raskolnikov's dream of the mare (PSS, 6:46-49), and mechta to signify conscious dreams, like killing the pawnbroker (6:275-78). In "Dream," these words signal the split between the Ridiculous Man's compassionate heart and his calculating mind. The Ridiculous Man's moral emotions give rise to philosophical questions: “My hatred for people on our earth always included anguish: why can I not hate them, not loving them, why can I not forgive them, and in my love for them there's anguish: why can I not love them, not hating them?" (25:114). The Ridiculous Man longs for authentic connection, but here Dostoevsky reveals that alienation from his own feelings impedes his narrator's connection to others. The Ridiculous Man cannot fully hate, love, or forgive because he suffers from a persistent shame that prevents him from seeing himself as a worthy self-presenting agent. ${ }^{20}$ Rather than attempting to repair the social bond, the Ridiculous Man withdraws.

20 Lansky, "Hidden Shame," 886. Lansky observes, "The inability to forgive often hides shame that attends one's complicity in betrayals and rejections." He also observes that shamed persons can act in a way that seems to solve the problem of "the shame of felt powerlessness, helplessness, contempt, and worthlessness" (including the act of withdrawal). Such acts then afford the shamed person "an experience of power (and possibly guilt) that also pushes shame into hiding" (ibid.). The philosopher David Velleman sees shame as anxiety about exclusion from the social realm where individuals act as self-presenting agents; see J. David Velleman, "The Genesis of Shame," Philosophy and Public Affairs 30, no. 1 (2001): 27-52. 
In his dream and in his confession, however, the Ridiculous Man tries to repair the social bond. He takes responsibility for the fall by claiming that he corrupts the dream people. Yet he seems to corrupt them not by anything he does, but by who he is - a fallen, shame-filled man, whose knowledge of good and evil infects others. The Ridiculous Man's dream thus echoes earlier Dostoevskian works: the Underground Man identifies consciousness as a disease, and Raskolnikov dreams of trichinae that infect individuals with a divisive hyperrationality. Yet these earlier cerebral protagonists consciously harm others, in part to alleviate the pain of their shame, ${ }^{21}$ whereas the Ridiculous Man simply acts as a source of consciousness. Unlike the Underground Man, who refuses to accept his guilt, and unlike Raskolnikov, who confesses but does not repent, ${ }^{22}$ the Ridiculous Man accepts both his fallen state and responsibility for others' fall. Like Eve and Adam in the garden of Eden, he first hides his shame and guilt but then confesses-he reaches out and accepts responsibility. Moreover, he believes that he can save those who laugh at him by sharing his shame-the universal, human condition.

The Ridiculous Man's toska thus shares the paradox of shame: separation entails union, a sense of longing implies a sense of loss. From story's beginning to end, Dostoevsky's first-person narrator is acutely aware of what he has lost, even if it may be a dream ideal of connection to all living things. And Dostoevsky, behind his narrator's back, associates that sense of loss and longing to the little star in the heavens and the little girl on earth. Initially the little star makes him think — "that little star gave me an idea" (PSS, 25:106) — and the little girl makes him feel- "I had felt pity not long ago" (25:107). The Ridiculous Man's awakened conscience moves him to speculate about what it means to be human: "It seemed clear that if I am a person, and still not nothing, and while I have not turned into nothing, then I live, and consequently can suffer, get angry, and feel shame for my actions" (25:107). The suffering, anger, and shame mentioned here reflect the action of the story's opening frame: the Ridiculous Man feels

21 Deborah A. Martinsen, "On Shame and Human Bondage," in Dostoevsky on the Threshold of Other Worlds: Essays in Honour of Malcolm V. Jones, ed. Sarah Young and Lesley Milne (Ilkeston, Derbyshire: Bramcote, 2006), 157-69; Martinsen, “Shame and Punishment," 51.

22 Richard J. Rosenthal, "Raskolnikov's Transgression and the Confusion between Destructiveness and Creativity," in Do I Dare Disturb the Universe? A Memorial to Wilfred R. Bion, ed. James Grotstein (Beverly Hills, CA: Caesura, 1981; London: Karnac Books, Maresfield Library, 1984), 197-235. 
pity for the young girl, angrily stomps his foot and yells at her, and then feels shame for his action. Dostoevsky thus demonstrates that the Ridiculous Man's moral emotions drive his actions and reflections.

The Ridiculous Man speaks of moral suffering, but early in the story Dostoevsky links moral and physical pain. The Ridiculous Man claims that he feels both: "You see: although it made no difference to me, I did, for example, feel pain. If someone were to strike me, I would feel pain. Exactly the same in the moral sense: if something very pitiful were to happen, I would feel pity, just as when things still made a difference to me in life" (PSS, 25:107). Dostoevsky identifies the Ridiculous Man's pity not only as a form of suffering but also as an emotion he felt before his revelation that nothing mattered. In his dream, the opposite holds. He feels moral, then physical pain: "A profound indignation suddenly burned in my heart, and I suddenly felt a physical pain in it" (25:110). Here Dostoevsky identifies the Ridiculous Man's indignation as a form of moral suffering that awakens his sense of bodily pain, thereby signaling his narrator's return to physical awareness. This reversal, emphasized by the repetition of the Dostoevskian "suddenly," prefigures the Ridiculous Man's final conversion.

Dostoevsky's pre-dream, pre-conversion narrator suffers from acute chronic shame-he sees himself as ridiculous in others' eyes. To protect himself, he owns the label "ridiculous" and guards this defensive knowledge with pride: "I was always so proud, that I would never under any circumstances acknowledge it to anyone" (PSS, 25:104). His pride leads to increased self-enclosure, which he equates with survival: "That pride grew in me ... and if it happened that I were to confess before anyone whomsoever that I was ridiculous, then it seems to me that I would on the spot, that very evening, shatter my head with a revolver" (25:104). As this confession reveals, the Ridiculous Man's shame is so acute that it has become a matter of life and death. In order to protect himself from the painful self-consciousness and vulnerability of connection, he withdraws emotionally. The Ridiculous Man thus suffers from what Taylor calls "a shriveled self," a condition accompanied by its own negative feedback loop: in depriving himself of interactions with others, he deprives himself of crucial knowledge about the world and himself. ${ }^{23}$

23 Taylor, Deadly Vices, 79. 
By closing down emotionally, the Ridiculous Man, like the Underground Man before him, loses the opportunity to know himself. Dostoevsky conveys the extent of the Ridiculous Man's narcissistic self-enclosure by having him wonder whether the world and its people are "I myself alone" (PSS, 25:108). This speculation reveals the paradox of pride: to desire is to want something one lacks, but the proud desire godlike perfection and self-sufficiency, a desire that leads to spiritual death ${ }^{24}$ (like Kirillov in Demons). The Ridiculous Man's pride leads to a self-enclosure so complete that he no longer feels a need to be in the world. His pride makes him feel that to have feelings is a weakness (like Raskolnikov in Crime and Punishment) and that to show them would betray a vulnerability so painful as to require complete extinction. The Ridiculous Man's moral emotions betray him. He thought that his indifference would protect him from the pain of being human, but his pity for the little girl causes him pain. He suffers morally because he identifies with her, and he experiences shame because he failed to live up to his false ideal of indifference. His moral emotions save him by changing his way of perceiving the world and his place in it.

Although Dostoevsky loads hyperrationality with negative connotations, he values philosophical speculation. ${ }^{25}$ Significantly, the Ridiculous Man's dream begins with moral speculation: if he were to commit a shameful act on the moon or Mars, would it matter to him? The Ridiculous Man thus asks himself, Am I a moral being or not? Even before providing the dream as answer, the story affirms that he is: his pity and shame mark the Ridiculous Man as a moral being. His philosophical question takes concrete form in the Ridiculous Man's dream travels, where he explicitly links the little girl to his love for the earth he has quitted. As he shakes with "an uncontrollable, ecstatic love for that former, native earth," which he had abandoned, the Ridiculous Man has a vision: "The image of the poor little girl, whom I had offended, flashed before me" (PSS, 25:111). The little girl connects him to life and love.

The Ridiculous Man's dream not only answers his speculation but heals the shamed-based alienation that causes him to drive the little girl away. Her plea for help awakens his moral emotions and thus prepares for the dream journey in which he feels connected to and responsible for others. His dream

24 Ibid., 80.

25 Frank, Mantle of the Prophet, 357-58. Frank speculates that "Dream" is a first version of a "Russian Candide," an idea Dostoevsky jotted down five months after writing the story. 
shows him that a meaningful life requires both emotional and intellectual engagement. It demonstrates that reasoning used as a defense harms, whereas reasoning used as a means of self-knowledge heals. In short, his dream heals the Ridiculous Man's divided self and gives meaning and purpose to his life. When he awakens, he seeks and finds that little girl.

By story's end, Dostoevsky has expanded the little girl's functions by creating a web of associations around her. At story's opening, she is the agent of the Ridiculous Man's change of heart and mind; at story's end, the vehicle for his expiation. Psychologically, she represents the narrator's vulnerable, abandoned self. Thematically, she represents connection to the earth, to the Ridiculous Man's native soil. And ideologically, she represents a pure Russia, uncontaminated by Western thought. In finding her, the Ridiculous Man thus enacts Dostoevsky's dream of pochvennichestvo-the union of Western-educated upper classes with the unlettered but Christ-following Russian masses.

By story's end, Dostoevsky has also expanded the little star's functions. Initially the agent of the Ridiculous Man's decision to kill himself, in mid-story the little star becomes the vehicle for his toska. Psychologically, the little star shifts association from the Ridiculous Man's choice of death to his love of life. Thematically, the little star mistaken for Sirius represents Enlightenment rationality and alienation from emotions, whereas the little star identified as earth represents Romantic longing and love for the fallen earth and its inhabitants. Once linked to the earth, the little star merges emotionally with the little girl, preparing for its ideological rebranding as Isis-Sirius, Mother Russia, the earth that gives him birth. The philosophical tale yields to the Christmas tale, in which the star leads the wise men to the Mother of God, or Bogoroditsa, the off-stage figure in this drama of compassion. ${ }^{26}$ It's not surprising that the Ridiculous Man calls the earth star rodnaya (from rod meaning "family or genus") and claims that it has rodnaya sila, or "native power" (PSS, 25:111). In the philosophical tale, Sirius is the home of Voltaire's space-traveling Enlightenment philosopher Micromegas, but Sirius is also mythically linked to the Christmas tale as the bright star that leads the magi to Bethlehem and as the star that signals the advent of Isis, the life-giving Egyptian maternal figure associ-

26 I am grateful to Richard Rosenthal for pointing out the importance of the off-stage mother (correspondence, February 28, 2014). 
ated with myths of death and reincarnation. Behind his narrator's back, Dostoevsky thus shows readers how the heart can change our perceptions: a star that leads to death can signal rebirth. Using the poetics of paradox, Dostoevsky activates our cognitive and affective faculties, challenging us to go beyond either/or thinking.

The dream gives Dostoevsky's narrator a new sense of self: he must preach the truth it has revealed to him. Although he has lost the words, he is sustained by the "living image" of the truth in his heart. ${ }^{27} \mathrm{He}$ knows that it is an ideal, not realizable on earth. He does not articulate Zosima's doctrine of all responsible for all, but he feels it. He now loves those who ridicule him: he identifies with them because they are like his pre-vision self. Full of pride, they are trapped in themselves and limited in their perceptions. They long for an Edenic unity but cannot find it. They project blame outward, mocking him rather than examining themselves.

As many great scholars have observed, the Ridiculous Man experiences conversion. He starts in a world of nothing matters (всё равно), a world where positive moral emotions like love, pity, and toska have been repressed by indifference. The little star in the Petersburg sky confirms this mental construct. The little girl on the Petersburg streets refutes it. She insists that things matter, her mother matters, she matters. Her plea for help proves that the Ridiculous Man's mental construct is a self-protective lie. His dream reveals the truth contained in the little girl's plea-all are responsible for all. Feelings of pity and love are natural parts of being human.

The Ridiculous Man's drama with little star, little girl, and toska has two acts. The first starts on earth and ends in his dream: the Ridiculous Man sees the little star, which can signify either religious hope or Enlightenment death; he chooses death, sees the little girl who restores him to life, and dream-travels past that little star, leaving his Enlightenment thinking behind. The second act starts in his dream and ends on earth: he sees another little star, which is the earth, experiences a rebirth, visits the prelapsarian earth, causes the fall, wakes up,

27 Jackson notes the difference between the Ridiculous Man's pravda (a "lower earthly truth of the flesh," i.e., that he has corrupted the dream people) and his istina ("a higher Truth of beauty and spirit"), which reflects "the paradoxical structure in Dostoevsky's philosophical thought: the notion of two kinds of beauty" (Art of Dostoevsky, 290-91). In my reading, the higher truth provides the answer to the Ridiculous Man's existential angst. 
finds the little girl, and starts preaching the truth of his vision. In act 1, the Ridiculous Man's toska is associated with his feelings of shame, alienation, and defensive indifference. In act 2, however, his toska expresses the natural condition of fallen humanity, an anguished longing for love and connection with other people and the divine.

In evoking the myth of the fall, Dostoevsky reminds us that the moral emotions of shame and guilt are the price of knowledge. "Dream" demonstrates that knowledge in the Dostoevskian world also comes with toska, a longing for lost unity with God and all living things. The story proposes that positive moral emotions represent the bridge back. The Ridiculous Man begins and ends his story by expressing love for those who ridicule him: he loves and identifies with them because they are like his pre-dream self, full of pride and blame, humans in a fallen world who erect defenses to protect themselves from knowledge of their incompleteness and of their responsibility for one another. Their longing for Eden expresses knowledge of lack. To lack is human; to strive is human; to love and be vulnerable is to be fully human, not self-sufficient but part of something higher. "The Dream of a Ridiculous Man" thus shows that the moral emotions, including toska, are essential to human community. For Dostoevsky, belief in something greater than self, something that links all living beings, is essential to morality. The Ridiculous Man concludes his story by stating his mission - to turn others around, that is, to convert them, so that they can see the beauty within. To do so, he argues, "the main thing is to love others as oneself"; and "The consciousness of life is higher than life, knowledge of the laws of happiness is higher than happiness'-that's what needs to be fought!" (PSS, 25:119). Dostoevsky's Ridiculous Man thus chooses Christian love over Enlightenment thinking. Romantic sentiment trumps Enlightenment reason. The philosophical tale is converted into a Christmas story. 